IP Periodica Polytechnica Civil Engineering

\author{
59(3), pp. 327 336 2015 \\ DOI: $10.3311 /$ PPci.7361 \\ Creative Commons Attribution (1) \\ RESEARCH ARTICLE
}

\section{Role of Integrated Parking Information System in Traffic Management}

\author{
Zsolt Péter Sándor, Csaba Csiszár
}

Received 18-02-2014, revised 04-12-2014, accepted 09-12-2014

\begin{abstract}
Management tasks of parking facilities (coordination of demand and supply) belong to mobility and traffic management, especially in the case of limited capacities. While researches regarding to parking problems usually focus on narrower fields (processes, implementation), claim for integrated, comprehensive traffic management appears even more intensively. The information technology offers a wide toolkit for this. The concept of the integrated parking management system has been elaborated. It takes into consideration the different characteristics of the parking methods. A ranking calculation method has been developed, which assesses the parking facilities and gives suggestions for the trip chain and the parking spot. This is based on time-dependent and ever-changing resistance values. The method takes into consideration the dynamic features of facilities, users' preferences and the applied management strategy. It can be used for the development of route guidance and navigation software. In the future, mobility and parking demands can be influenced by real-time and interactive information management via smartphones. These equipments became personal intelligent travel assistant devices.
\end{abstract}

\section{Keywords}

intelligent parking $\cdot$ parking demands $\cdot$ capacity $\cdot$ traffic management $\cdot$ demand and capacity coordination

\section{Zsolt Péter Sándor}

Department of Transport Technology and Transport Economics, Budapest University of Technology and Economics, Múegyetem rkp. 3-5, H-1111 Budapest, Hungary

e-mail: zsolt.sandor@mail.bme.hu

\section{Csaba Csiszár}

Department of Transport Technology and Transport Economics, Budapest University of Technology and Economics, Múegyetem rkp. 3-5, H-1111 Budapest, Hungary

e-mail: csiszar.csaba@mail.bme.hu

\section{Introduction}

The road traffic management covers: (1) management of moving traffic and (2) management of "standing" traffic (including searching for parking places as well). Demand management of road transport networks includes also tasks regarding parking facilities. During traffic management, parking problems can be avoided or managed efficiently with the operation of parking information systems and with the interconnection of them with other management systems.

In congested urban areas and also in the parking facilities along the motorways, the parking demands usually exceed capacities. The solution requires network-wide approach and interventions [1]. Parking pricing is an efficient and widely accepted measure for modal split management [2], for reducing congestion on urban road networks [3], and for managing the parking demands in urban zones of high attractiveness [4]. Realtime local information provision can mitigate local problems but the network-wide problems require integrated solutions. It can be aided by IT systems [5], [6]. In urban areas there are several methods for parking. [7] summarizes these ones with their informatics specialities. There are numerous applications and projects that give real-time information about the parking status of a certain area. During the past two decades, traffic authorities in many cities (Helsinki, Cologne, Mainz, Stuttgart, Wiesbaden, Aalborg, Hague) have started to inform and guide drivers to parking facilities with real-time variable message signs [guiding arrows, names of the parking facilities, status, number of available parking spaces, etc.]. Information about the number of available parking spaces could be displayed on the major roads, streets and intersections, or it could be transmitted through the Internet. Several cities use webpages and smartphone applications for this purpose [8-10], (www.sfpark.org), (parken.heidelberg.de). Parking management includes several methods, solutions and tools [11]. With them parking capacities and demands can be adjusted to each other. Some countries [12, 13] apply design standards and/or guidelines for planning in the major transport projects. In the future, the role of parking management should be strengthened, because structures of cities are changing and environmental aspects are also significantly 
considered. Other aspects like land use plans and long-term territorial development strategies are also taken into consideration when the designers are trying to find the best solutions for parking and traffic related problems in big cities [14-16]. [17] considers the inter-relationship between on-street parking and choice of mode for journeys to work in Edinburgh. The article concludes that habit modification methods are transferable to other cities but that the scale of the impacts in each will be related to site specific factors. [18] created a model for evaluating parking users' behavior. It was determined that parking information are vital in the Advanced Traveller Information Systems.

In this paper, features and functions regarding "base" and information processes of the certain parking methods have been summarized. On base of it, a proposal for the functional and structural model of the integrated information system has been created. Assignment of parking demands (which are originated from the mobility demands) to free parking capacity is a cardinal operational task. The personal preferences of travellers and hauliers should be also taken into consideration. As a solution, a process incorporating real-time parameters and requirements has been elaborated. With this procedure an individual resistance factor is quantifiable for each parking facility.

\section{Parking methods and functions of the parking infor- mation systems}

Parking methods can be grouped according to the ownership (public and private), location and layout (connecting infrastructure) of the facility [7]. The most common public parking methods are the followings, where parking demands often exceed capacity [1]:

- side and roadside parking,

- car storage on a parking lot,

- parking in a multi-storey car park or

- parking in a motorway parking facility.

Parking places are mainly selected with consideration to several aspects. Among these features there are facility parameters (location, layout, terms of use, safety and security solutions, etc.), personal preferences and characteristics of the travel chain. Users take several parameters with different "weights" into consideration during their decisions. For example: street parking is often preferred to parking in multi-storey car park. Its main reasons: lower fees, simplicity and quickness of parking manoeuvres as well as easy exploration of free parking places, etc. Table 1 summarizes the functions of the parking management and information system, following the processes of travel chains.

\section{Methodology}

The structure of and integrated parking management system and base parking-related processes have been examined with system and process oriented approach. As the operation of every
ITS application, the operation of parking management system is also decomposable for three main parts:

1 data acquire,

2 data processing and

3 information provision.

The structure of the system follows this three-level scheme.

\subsection{Structure of the integrated system}

Main informatics components (elements, subsystems) of the parking management system:

- User: with personal devices that support two-way communication. These equipment can be applied as on-board units too - navigation devices, smart phones, palmtop, laptop, (even $P C)$;

- Haulier company: management (control) information systems;

- Vehicle: with on-board hardware elements and database, with multichannel communication equipment that aid the operation of safety systems too $(I 2 \mathrm{~V}, \mathrm{~V} 2 \mathrm{~V})$;

- Mobility management centre: with human and machine elements, with central databases (traffic parameters and management plans, network, etc) and with multichannel communication solutions (wired and wireless communication, public and dedicated communication channels [internet, intranet, Wi-Fi, mobile internet, GPRS, UMTS, etc.]);

- Parking management centre: it is a part of the mobility management centre; with human (operator, parking inspector) and machine elements, with integrated central databases (dynamic and static data regarding the facilities, (pre-)bookings, vehicles, users, invoices and payment);

- Parking facility: with IT peripheries aiding vehicle storage. Active and passive safety systems that protect pedestrians against running over accidents and protect vehicles from bump, crash and slam using acoustic and visual signals. Lighting equipment built in the road surface (LED markers, LED prisms), variable message sings and occupancy detectors (loops, ultrasonic sensors, etc) are parts of the control systems. Image processing and identification devices (cameras, user identification and license plate recognition systems), access control system with physical barriers and human components for surveillance, safeguard and inspection are parts of the safety and security systems. Card readers that eliminate cash, (multilane) free-flow vehicle identification with DSRC (Dedicated Short Range Communication) and certain safety devices are parts of the payment subsystem. The core of the complete parking management system is the data collection that is realized by data collection devices at the facilities. 
- Road operator company: with roadside data collection, information, intervention and communication devices, and with central database containing road parameters as well as restrictions and road works, etc.;

- Public transport company: with information and communication systems that relate to vehicle control and fleet management (GIS database for routes, database for schedules, fares, etc)

The listed elements are connected in the indicated relations by telecommunication channels (wired and wireless data networks). The structure of the system is illustrated on Fig. 1. Only one element of each component is represented. Management centres and most of the parking facilities are operated with nonstop human supervision. Public transport companies and road management companies are beyond the system boarder, they belong to the environment of the system.

Information terminals:

- Mobile devices (On-board): personal and/or vehicle devices with own operating system (iOS, Android, Symbian, etc), with multi-channel communication units (GPS, GSM, Wi-Fi aerial, etc.), with navigation and route planning programs that provide real-time information and direct parking lot booking.

- Immobile devices (Off-board): road traffic signs, displays (latter are part of the intelligent road infrastructure).

- Static signs: conventional traffic signs for route guidance with auxiliary signs (name, distance, direction, zone, etc.). Value set consists of one element.

- Semi-dynamic signs: give information about status of the facility using auxiliary (mainly) prismatic sign. Value set consists of three elements (free, full, and closed).

- Dynamic signs: real-time occupancy information. Not only the facilities but the zones (with total capacity) may be concerned. Value set consists of infinity elements.

- Multi-functional, intelligent displays: They can display further (e.g. public) transport information, too. (E.g.: expected arrival time of the following public transport vehicle, etc.)

- LED marker: located in the parking facility; light equipments built in the road surface and consist of controllable prisms. Vehicles can be guided to the parking lot by it.

Potential of smartphones and internet are exploited by operators of parking facilities in regions and/or cities where mobility management is well-developed. They work independently or jointly. Websites and smartphone applications have been also developed. Users can select facilities, can browse static and dynamic facility information and can book parking lots on them [8. 9], (www.sfpark.org), (parken.heidelberg.de).

Costs of the complete system are depending on the applied technological solutions. Appropriate communication between the components is essential. Communication between vehicles and the management centre and between the management centre and facilities are indispensable. In case of redundant and highly secured systems the communication between vehicles and facilities are dispensable. Mobile communication (3G, 4G) can offer a low and affordable cost for vehicles. In case of the loss of data connection, voice based communication can be applied.

Failures in the central computers cause serious problems. Thus fail-safe operation has to be guaranteed.

\subsection{Operation of the integrated system}

Most important objectives of parking management and trip planning processes:

- low time consumption (for parking place searching, entrance and exit, payment, walking, etc), reliable, calculable and predictable travel time;

- decrease unnecessary travel distances and emission, mitigation of noise pollution;

- decrease stress, increase user comfort;

- decrease accident risk;

- protection of vehicles,

- enhancing reliability of IT and intervention systems [6].

Operational processes of the telematics system are summarized on Fig. 2, which is coherent with structural architecture. Table 2 contains the description of information operations regarding parking management system (following the base process). Numbers refer to the operations. Some processes may be cited several times.

Parking facility operators have to accept and obey the operational rules. This is the precondition of the traffic management supported by integrated information system. Operators should give some functions (demand management, navigation, determination of dynamic parking rates, etc.) to the parking management centre over.

\section{Result - Determination of traffic and parking manage- ment strategy}

Management strategy is selected by incoming data and information. The measures are determined on base of the strategy, and some of them regard to parking management.

Three control methods can be applied considering the spatial coverage:

1 local control,

2 line control,

3 network control (with zones).

These methods are used separately or in combined way. Features of the control methods are summarized on Table 3 .

Basis of the operation is the knowledge about mobility demands and actual status of network elements. In a radial-ring 
Tab. 1. Functions of information systems in line with the processes of trip chains

\begin{tabular}{|c|c|c|c|c|c|c|}
\hline Functions & a., pre trip & $\begin{array}{l}\text { b. on-trip, } \\
\text { approach- } \\
\text { ing } \\
\text { parking } \\
\text { facility }\end{array}$ & $\begin{array}{l}\text { c. at } \\
\text { parking } \\
\text { facility }\end{array}$ & $\begin{array}{l}\text { d. on-trip, } \\
\text { leaving } \\
\text { parking } \\
\text { facility }\end{array}$ & e. post-trip & Solutions \\
\hline $\begin{array}{l}\text { 1. infor- } \\
\text { mation } \\
\text { dissemi- } \\
\text { nation }\end{array}$ & \multicolumn{2}{|c|}{$\begin{array}{l}\text { accessibility of parking } \\
\text { facility, actual capacity, } \\
\text { terms of use, fees, } \\
\text { payment methods, public } \\
\text { transport connections, etc. }\end{array}$} & $\begin{array}{c}\text { terms of } \\
\text { use, fees, } \\
\text { payment } \\
\text { methods, } \\
\text { public } \\
\text { transport } \\
\text { connec- } \\
\text { tions, } \\
\text { etc. }\end{array}$ & $\begin{array}{l}\text { payment } \\
\text { methods, } \\
\text { fees, etc. }\end{array}$ & $\begin{array}{l}\text { [measure of } \\
\text { user } \\
\text { satisfaction] }\end{array}$ & $\begin{array}{l}\text { based on static data (location, capacity, services, } \\
\text { public transport connections, etc.)based on real-time } \\
\text { and predicted parameters (actual occupancy, } \\
\text { departure time of public transport vehicles)fix and } \\
\text { variable message sings,internet based information } \\
\text { dissemination and route planning,location-based } \\
\text { services (navigation) }\end{array}$ \\
\hline $\begin{array}{l}2 . \\
\text { demand } \\
\text { manage- } \\
\text { ment } \\
\text { (book- } \\
\text { ing) }\end{array}$ & \multicolumn{2}{|c|}{$\begin{array}{l}\text { selection of parking } \\
\text { facility, booking of parking } \\
\text { place, [input of parking } \\
\text { duration] (modification } \\
\text { and cancellation of } \\
\text { reservation) }\end{array}$} & $\begin{array}{l}\text { "check-in" } \\
\text { [record of } \\
\text { parking } \\
\text { duration] }\end{array}$ & „check-out” & $\begin{array}{c}\text { collection of } \\
\text { occupancy } \\
\text { data (user } \\
\text { groups, } \\
\text { vehicle } \\
\text { categories, } \\
\text { temporal } \\
\text { characteris- } \\
\text { tics) } \\
\end{array}$ & $\begin{array}{c}\text { (registration), vehicle (user) identification, telephone } \\
\text { service, internet-based booking as part of route } \\
\text { planning,input and output counting, detection of } \\
\text { parking lot occupancy (loops, ultrasonic sensors, } \\
\text { etc.), traffic forecast }\end{array}$ \\
\hline $\begin{array}{l}\text { 3. navi- } \\
\text { gation } \\
\text { (in-door } \\
\text { and out- } \\
\text { door) }\end{array}$ & $\begin{array}{l}\text { route } \\
\text { guidance } \\
\text { (related to } \\
\text { the parking } \\
\text { facility } \\
\text { selection) }\end{array}$ & $\begin{array}{l}\text { vehicle } \\
\text { navigation }\end{array}$ & $\begin{array}{l}\text { in-door } \\
\text { vehicle and } \\
\text { pedestrian } \\
\text { navigation }\end{array}$ & $\begin{array}{c}\text { vehicle } \\
\text { navigation }\end{array}$ & $\begin{array}{l}\text { origin and } \\
\text { destination } \\
\text { point of users } \\
\text { (spatial char- } \\
\text { acteristics) }\end{array}$ & $\begin{array}{l}\text { fix and variable message sings (information design), } \\
\text { lighting equipment built in the road surface [LED } \\
\text { displays and markers],vehicle (user) identification, } \\
\text { location-based services, use of static and dynamic } \\
\text { data, individual (personalized) and collective } \\
\text { guidance }\end{array}$ \\
\hline $\begin{array}{l}\text { 4. pay- } \\
\text { ment, } \\
\text { fee col- } \\
\text { lection }\end{array}$ & $\begin{array}{l}\text { informatior } \\
\text { and oper } \\
\text { collectio }\end{array}$ & $\begin{array}{l}\text { about fees } \\
\text { on of fee } \\
\text { system }\end{array}$ & $\begin{array}{l}\text { prior } \\
\text { payment of } \\
\text { parking } \\
\text { fees }\end{array}$ & $\begin{array}{l}\text { post } \\
\text { payment of } \\
\text { parking } \\
\text { fees } \\
\text { (correction } \\
\text { of prior } \\
\text { fees, } \\
\text { penalties) }\end{array}$ & post payment & $\begin{array}{l}\text { (registration), prior payments (with post-adjustment) } \\
\text { - during preparatory phase or at entering; post } \\
\text { payment - at leaving the parking facility or at the end } \\
\text { of a time period;in cash, with credit card/mobile } \\
\text { phone/parking card or direct debit on a bank } \\
\text { account;as part of route planning (internet-based or } \\
\text { on-board), (public transport ticket purchase) }\end{array}$ \\
\hline $\begin{array}{l}\text { 5. safety } \\
\text { (preven- } \\
\text { tion of } \\
\text { acci- } \\
\text { dents) }\end{array}$ & $\begin{array}{l}\text { warning } \\
\text { about } \\
\text { dangers, } \\
\text { information } \\
\text { about } \\
\text { intelligent } \\
\text { functions }\end{array}$ & $\begin{array}{l}\text { intelligent } \\
\text { vehicle } \\
\text { functions } \\
\text { (driving } \\
\text { aiding } \\
\text { solutions) }\end{array}$ & $\begin{array}{l}\text { active and } \\
\text { passive } \\
\text { solutions } \\
\text { (monitoring } \\
\text { of vehicle } \\
\text { and } \\
\text { pedestrian } \\
\text { move- } \\
\text { ments) }\end{array}$ & $\begin{array}{l}\text { intelligent } \\
\text { vehicle } \\
\text { functions } \\
\text { (driving } \\
\text { aiding } \\
\text { solutions) }\end{array}$ & $\begin{array}{l}\text { evaluation of } \\
\text { operation of } \\
\text { intelligent } \\
\text { systems (use } \\
\text { of video } \\
\text { records in } \\
\text { proof- } \\
\text { procedures) }\end{array}$ & $\begin{array}{l}\text { vehicle and pedestrian detection + variable message } \\
\text { sign and/or sound signalpassive solutions (mirrors, } \\
\text { acoustic road markings, protection layers against } \\
\text { slam and crash, road markings, physical barriers, } \\
\text { etc.)active solutions [intelligent vehicle functions] } \\
\text { (I2V, V2V communication, rear parking sensors, } \\
\text { automatic parking systems, etc.) }\end{array}$ \\
\hline $\begin{array}{l}6 . \\
\text { security } \\
\text { (preven- } \\
\text { tion of } \\
\text { theft and } \\
\text { vandal- } \\
\text { ism) }\end{array}$ & $\begin{array}{l}\text { information } \\
\text { about } \\
\text { security } \\
\text { systems }\end{array}$ & monitoring & f vehicles and & ersons & $\begin{array}{l}\text { use of video } \\
\text { records in } \\
\text { proof- } \\
\text { procedures }\end{array}$ & $\begin{array}{l}\text { video surveillance and/or recording, identification } \\
\text { procedures for vehicles and/or persons (license plate } \\
\text { recognition, card for identification, etc.), security staff }\end{array}$ \\
\hline
\end{tabular}




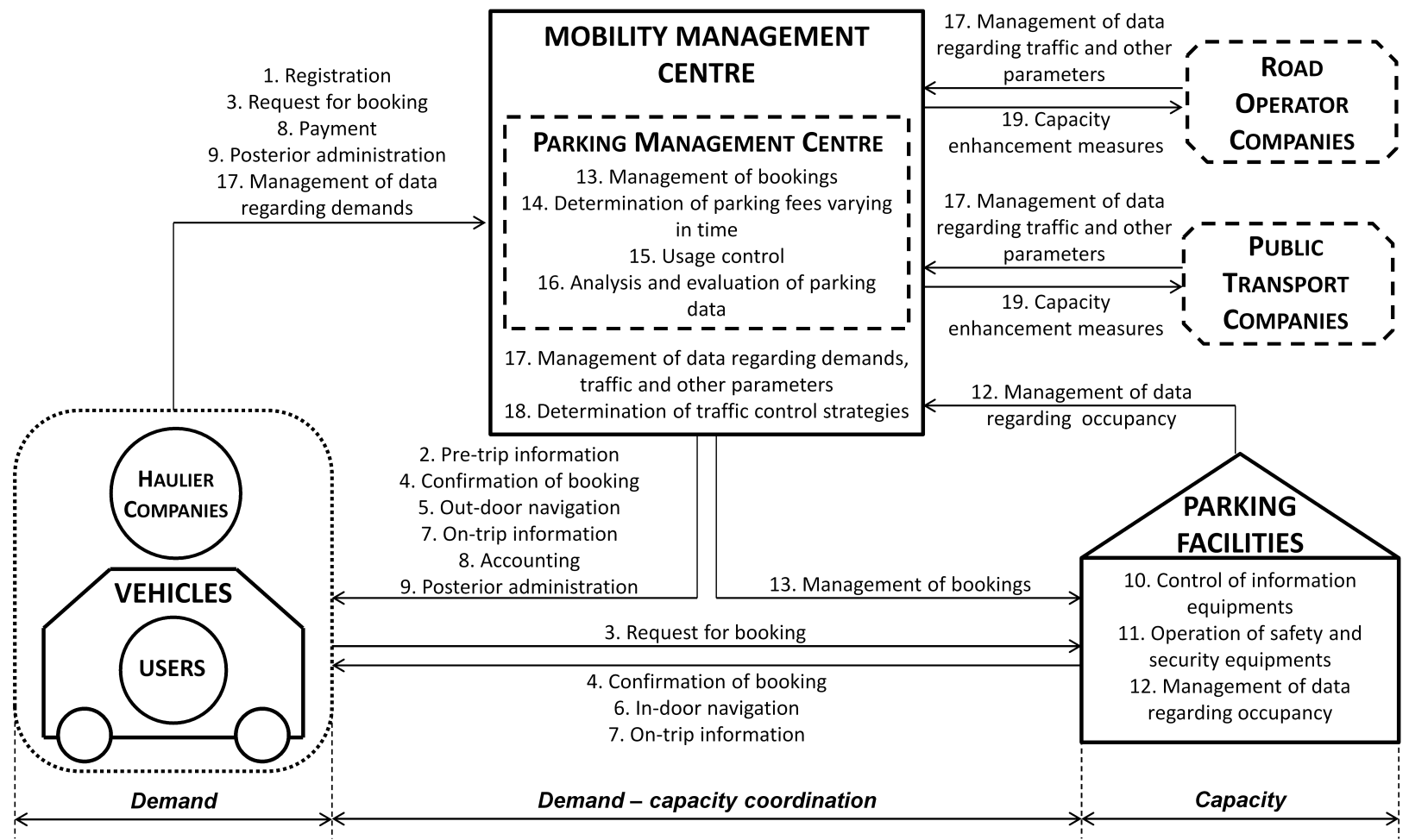

Fig. 1. Structural architecture of the parking management system. Source: own edition

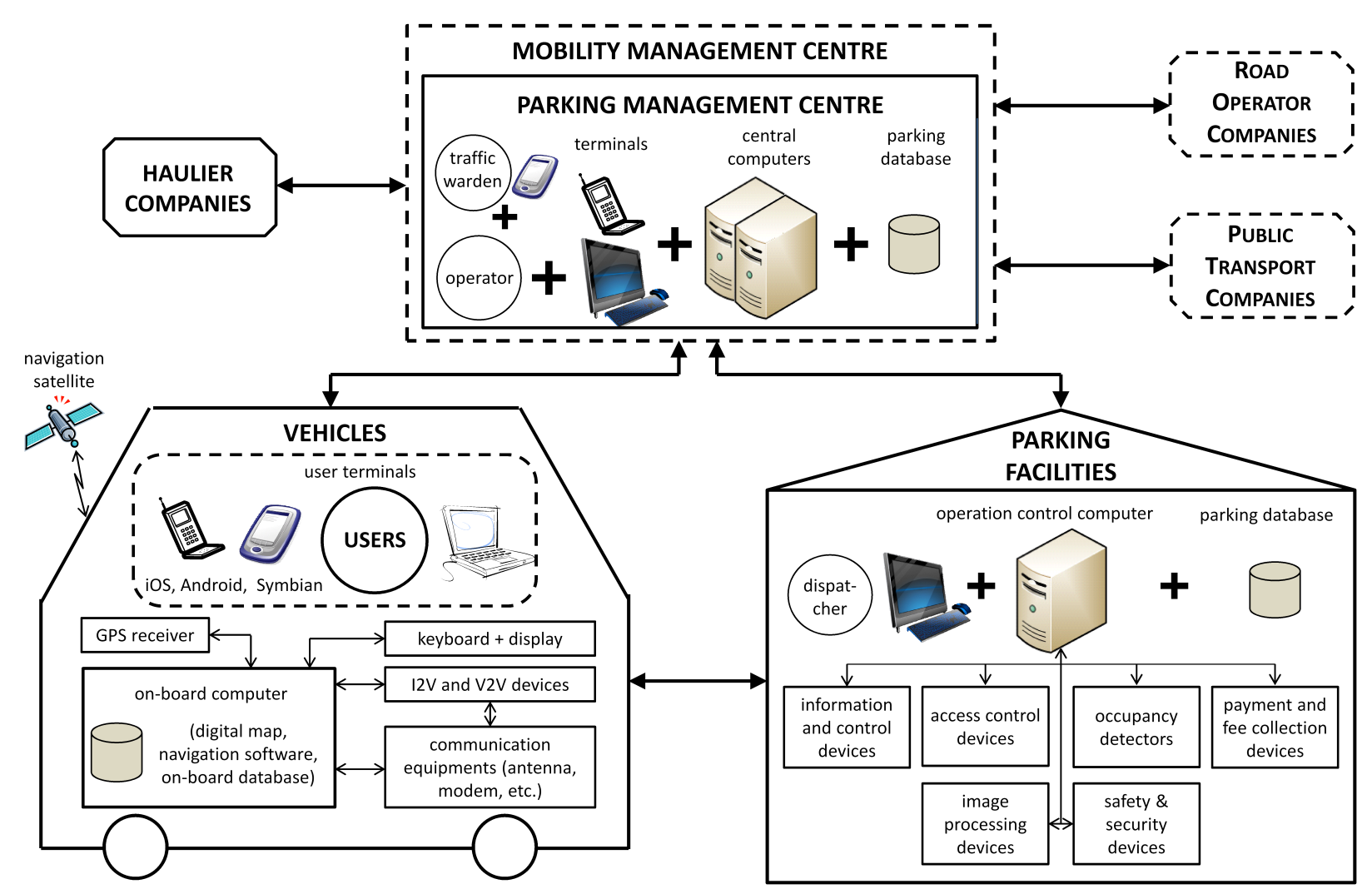

Fig. 2. Operation model of parking management system. Source: own edition 
Tab. 2. Parking-related information management operations

\begin{tabular}{|c|c|c|c|c|}
\hline groups & operation & no. & name & description \\
\hline \multirow{9}{*}{ 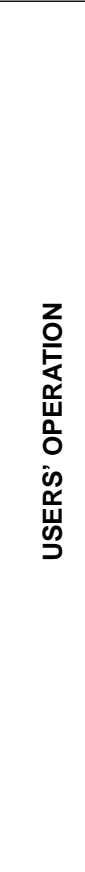 } & \multirow{4}{*}{ Pre-trip } & 1. & Registration & $\begin{array}{l}\text { Input of data regarding customers, vehicles, payment, } \\
\text { invoice and personal preferences. }\end{array}$ \\
\hline & & 2. & Pre-trip information & $\begin{array}{c}\text { Static and dynamic (real-time) information about facilities } \\
\text { (location, layout, services, fees, terms of use, occupancy, } \\
\text { public transport connections, etc.) }\end{array}$ \\
\hline & & 3. & Request for booking & $\begin{array}{l}\text { Direct booking without route planning or parking place } \\
\text { selection as a part of route planning (input of personal } \\
\text { parking preferences) and then booking. Users without } \\
\text { registration can book parking places directly at the facility. }\end{array}$ \\
\hline & & 4. & Confirmation of booking & Information about the features of the booked place. \\
\hline & \multirow{3}{*}{ On-trip } & 5. & Out-door navigation & $\begin{array}{l}\text { Real-time navigation (considering actual traffic conditions) } \\
\text { based on the selected parking facility and route; modification } \\
\text { of trip chain (and parking lot booking) if necessary. [This } \\
\text { process is related to the traffic management function]. }\end{array}$ \\
\hline & & 6. & In-door navigation & Guidance to the booked parking lot in the facility. \\
\hline & & 7. & On-trip information & $\begin{array}{l}\text { (Static and real-time) information about leaving the facility } \\
\text { and onward travel (e.g.: public transport lines, schedules, } \\
\text { vehicle positions, fares, discounts, terms of use). }\end{array}$ \\
\hline & \multirow[t]{2}{*}{ Post-trip } & 8. & Accounting, payment & $\begin{array}{l}\text { Invoicing at the end of parking or at the end of a time period, } \\
\text { pay off invoices. }\end{array}$ \\
\hline & & 9. & Posterior administration & Customer service and compliant management. \\
\hline \multirow{3}{*}{ 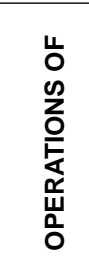 } & \multirow{3}{*}{ 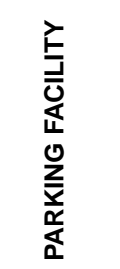 } & 10. & $\begin{array}{l}\text { Control of information } \\
\text { equipments }\end{array}$ & Operation of the facility equipments. \\
\hline & & 11. & $\begin{array}{l}\text { Operation of safety and } \\
\text { security equipments }\end{array}$ & $\begin{array}{l}\text { Two-way communication with the active and passive safety } \\
\text { and security equipments. }\end{array}$ \\
\hline & & 12. & $\begin{array}{l}\text { Management of data } \\
\text { regarding occupancy }\end{array}$ & $\begin{array}{l}\text { Acquirement of occupancy data with use of detectors, data } \\
\text { transfer to the parking management centre. }\end{array}$ \\
\hline \multirow{4}{*}{ 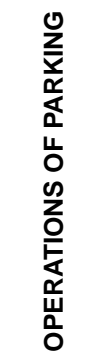 } & \multirow{4}{*}{ 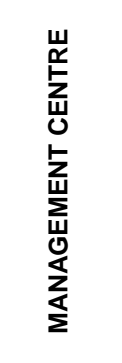 } & 13. & Management of bookings & Assignment of free parking lots to the booking demands. \\
\hline & & 14. & $\begin{array}{l}\text { Determination of parking fees } \\
\text { varying in time }\end{array}$ & $\begin{array}{l}\text { Determination of dynamic parking fees depending on traffic } \\
\text { management strategies and other parameters (e.g. part of } \\
\text { the day, occupancy, etc.) }\end{array}$ \\
\hline & & 15 & Usage control & Control of usage and payment \\
\hline & & 16. & $\begin{array}{l}\text { Analysis and evaluation of } \\
\text { parking data }\end{array}$ & $\begin{array}{c}\text { Analysis and evaluation of users' behaviour and operations; } \\
\text { preparation of statistics and traffic predictions as well as } \\
\text { future decisions of developments. }\end{array}$ \\
\hline \multirow{3}{*}{ 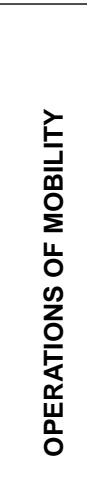 } & \multirow{3}{*}{ 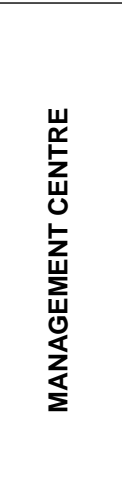 } & 17. & $\begin{array}{l}\text { Management of data } \\
\text { regarding demands, traffic } \\
\text { and other parameters }\end{array}$ & $\begin{array}{l}\text { Acquirement, processing, evaluation (and prediction) of user } \\
\text { demand data originating from user devices; as well as static, } \\
\text { semi-dynamic and real-time traffic data from public transport } \\
\text { and road operator companies (schedules, vehicle positions, } \\
\text { fares, traffic volume, travel times, congestions, road works, } \\
\text { etc.). }\end{array}$ \\
\hline & & 18. & $\begin{array}{l}\text { Determination of traffic control } \\
\text { strategies }\end{array}$ & $\begin{array}{l}\text { Selection of traffic control strategies depending on traffic } \\
\text { volume and other parameters (e.g.: environmental effects) } \\
\text { and determination of associated parameters. }\end{array}$ \\
\hline & & 19. & $\begin{array}{l}\text { Capacity enhancement } \\
\text { measures }\end{array}$ & $\begin{array}{l}\text { E.g. indication of supplementary capacity demands towards } \\
\text { the public transport operators and/or road operators for } \\
\text { preparation of traffic interventions. }\end{array}$ \\
\hline
\end{tabular}

Source: (own edition) 
Tab. 3. Parking control methods

\begin{tabular}{|c|c|c|}
\hline control methods & features & $\begin{array}{l}\text { roadside information dissemination } \\
\text { methods(about free capacity) }\end{array}$ \\
\hline 1. local & facilities are controlled one by one & at the entrance of the facility \\
\hline 2. line & $\begin{array}{c}\text { central control of several facilities on a certain } \\
\text { section and on its direct surrounding [it is } \\
\text { general at parking facilities of the motorway } \\
\text { network] }\end{array}$ & $\begin{array}{c}\text { display aggregated free capacity at the } \\
\text { beginning of each section + display free } \\
\text { capacity of the facility at the facility entrance } \\
\text { and the free capacity of the following facilities }\end{array}$ \\
\hline 3. network & $\begin{array}{c}\text { central control of major areas (zones, quarters, } \\
\text { districts, etc.) }\end{array}$ & $\begin{array}{l}\text { display aggregated free capacity of the zone a } \\
\text { zone entrances }+ \text { in the zones: display the } \\
\text { locations and the free capacities of the facilities }\end{array}$ \\
\hline
\end{tabular}

Source: (own edition)

structured city the saturation affects first usually the city core and it spreads outwards depending on the "elasticity" of the traffic. Therefore inner zones and city centre should be first of all protected by traffic interventions. From the users' aspect, management strategy consists of two parts [1]:

- soft intervention: users get information and suggestions about parking opportunities, public transport connections, etc.;

- hard intervention: management centre introduces traffic restrictions (road closures, entrance prohibition, etc.) and modifies parking and enter fees dynamically depending on demands (e.g. increase of parking fees in inner zones in case of congested traffic).

With use of the dynamic parking and public transport information the modal split can be shifted towards public transport. Places and/or times of activities can also be modified. The strategy elements for three different traffic situations are illustrated in Table 4 Types of measures depend mainly on traffic demands and location of network elements. But these are also significantly influenced by accidents, weather, air pollution and actual network restrictions [12].

For control of vehicle movements and aiding parking place selection a process has been elaborated. With this timedependent resistance factor can be assigned to each parking facility. This dimensionless value expresses that a certain facility is recommended for a user or not. Resistance values are positive numbers. They are determined by user preferences, static and dynamic features of facilities. Facilities with lower resistance value are more favourable for users.

Trip chains can be influenced by knowing of user preferences and determination of actual resistance values of routes. This can be used for development of route planning and navigation software. The resistance of a certain facility can be calculated using the following formula:

$$
r=\bar{s} \cdot \bar{p}_{s}^{T}+\bar{d} \cdot \bar{p}_{d}^{T}
$$

where

$r \quad$ resistance (dimensionless value),

$\bar{s} \quad$ vector of static features, $\bar{p}_{s} \quad$ vector of personal preferences for static features,

$\bar{d} \quad$ vector of dynamic features,

$\bar{p}_{d} \quad$ vector of personal preferences for dynamic features.

Static and dynamic vectors consist of coordinates that characterize static and dynamic (varying) features of parking facilities. Coordinates are determined by the operators based on predefined methodology (e.g. based on handbooks, manuals, system descriptions, etc.) taking general user habits and attitude into account. Values of coordinates are between 0-1, where the lower values are the better.

Coordinates of static vector:

$\bar{s}=\left[\begin{array}{llllll}s_{1} & s_{2} & s_{3} & s_{4} & s_{5} & s_{6}\end{array}\right]$

$\mathbf{s}_{\mathbf{1}}$ characteristics of location (accessibility, public transport connections, etc.);

$\mathbf{s}_{2}$ layout, characteristics of manoeuvres (outdoor layout, number of levels, characteristics of pedestrian movements, walking distances, automated parking house with mechanized vehicle movement, etc.);

$\mathbf{s}_{\mathbf{3}}$ terms of use (registered and/or ad hoc users; vehicle dimensions, fuel type; payment options, etc.);

$\mathbf{s}_{\mathbf{4}}$ information management (simplicity of usage, operation of fee collection system, information about public transport and other services, etc.);

$\mathbf{S}_{5}$ safety (active and passive safety systems enhancing transport and vehicle safety, parking sensors, $\mathrm{I} 2 \mathrm{~V}$ communication, mirrors, etc.);

s6 security (non-stop safeguarding, presence of dispatcher, vehicle and user identification devices, etc.).

Coordinates of dynamic vector: $\bar{d}=\left[\begin{array}{ll}d_{1} & d_{2}\end{array}\right]$

d$_{1}$ preference value (depends on the location and occupancy of the facility, with consideration to the management strategy), [If the traffic should be mitigated in the vicinity of the facility, or when the occupancy of the facility is high, the value of this parameter is high. When occupancy is $100 \%$ or it is very close to it, the role of human factor and the role of operators are getting into the focus.]

$\mathbf{d}_{\mathbf{1}}$ fees (depends on occupancy and management strategy as well as fees of other facilities. Fees are compared to each others. In case of free of charge this value is zero.) 
Tab. 4. Characteristics of traffic management strategies

\begin{tabular}{|c|c|c|c|}
\hline Traffic volume & Fees of parking facilities & $\begin{array}{l}\text { Management of public } \\
\text { transport }\end{array}$ & Control of road traffic \\
\hline off-peak traffic & low fees & off-peak schedule & minimal delay \\
\hline rush-hour traffic & $\begin{array}{l}\text { high fees in the } \\
\text { downtown, low fees in the } \\
\text { suburb (e.g. Park and } \\
\text { Ride facilities), downtown } \\
\text { facility pricing is in line } \\
\text { with the saturation of the } \\
\text { city/zone/network }\end{array}$ & $\begin{array}{l}\text { rush hour schedule, free } \\
\text { public transport when } \\
\text { user uses a Park and } \\
\text { Ride facility }\end{array}$ & $\begin{array}{c}\text { public transport have } \\
\text { priority }\end{array}$ \\
\hline $\begin{array}{c}\text { extremely high traffic } \\
\text { (e.g. Christmas shopping } \\
\text { period) }\end{array}$ & $\begin{array}{l}\text { extremely high, deterrent } \\
\text { fees in the downtown, } \\
\text { fees are progressively } \\
\text { decreasing towards the } \\
\text { suburbs }\end{array}$ & $\begin{array}{l}\text { enhanced capacity } \\
\text { (shorter following } \\
\text { intervals), fares discounts }\end{array}$ & $\begin{array}{l}\text { entrance restrictions for } \\
\text { crowded areas, public } \\
\text { transport have } \\
\text { priority,traffic light } \\
\text { "protection" for downtown } \\
\text { and for main road } \\
\text { corridors }\end{array}$ \\
\hline
\end{tabular}

Tab. 5. Static and dynamic characteristics of parking facilities (example)

\begin{tabular}{|c|c|c|c|c|c|c|c|c|c|}
\hline & \multirow{2}{*}{ characteristics } & \multicolumn{6}{|c|}{$\overline{\mathbf{s}}$} & \multicolumn{2}{|c|}{$\overline{\mathbf{d}}$} \\
\hline & & $\mathbf{s}_{1}$ & $\mathbf{s}_{2}$ & $\mathbf{S}_{3}$ & $\mathbf{s}_{4}$ & $\mathbf{S}_{5}$ & $\mathbf{S}_{6}$ & $d_{1}$ & $d_{2}$ \\
\hline suburban parking area & $\begin{array}{l}\text { outdoor parking, without major public transport } \\
\text { connections, limited operation hours }(6-22)\end{array}$ & 0,1 & 0,4 & 0,8 & 0,8 & 0,1 & 0,8 & 0,2 & 0 \\
\hline guarded park and ride facility & $\begin{array}{l}\text { with major public transport connections } \\
\text { (e.g. subway station), outdoor parking }\end{array}$ & 0,6 & 0,5 & 0,3 & 0,5 & 0,5 & 0,2 & 0,1 & 0,3 \\
\hline $\begin{array}{l}\text { automated multi-storey } \\
\text { car park, in the downtown }\end{array}$ & near frequented traffic facilities & 0,1 & 0,1 & 0,2 & 0,2 & 0,1 & 0,1 & 0,8 & 0,6 \\
\hline
\end{tabular}

Source: (own edition)

Tab. 6. Personal preferences of different user groups (example)

\begin{tabular}{|c|c|c|c|c|c|c|c|c|c|}
\hline & \multirow{2}{*}{ characteristics, requirements } & \multicolumn{6}{|c|}{$\overline{\mathbf{p}}_{\mathbf{s}}$} & \multicolumn{2}{|c|}{$\overline{\mathbf{p}}_{\mathbf{d}}$} \\
\hline & & $\mathbf{p}_{\mathrm{s} 1}$ & $\mathbf{p}_{\mathrm{s} 2}$ & $\mathbf{p}_{\mathrm{s} 3}$ & $\mathbf{p}_{\mathrm{s} 4}$ & $\mathbf{p}_{\mathrm{s} 5}$ & $\mathbf{p}_{\mathrm{s} 6}$ & $\mathbf{p}_{\mathrm{d} 1}$ & $\mathbf{p}_{\mathrm{d} 2}$ \\
\hline commuting employee & $\begin{array}{l}\text { low-priced, with appropriate public transport } \\
\text { connections, avoid traffic congestions }\end{array}$ & 0,5 & 0,25 & 0,25 & 1 & 0,5 & 0,5 & 1 & 1 \\
\hline $\begin{array}{l}\text { employee with high } \\
\text { mobility demands }\end{array}$ & $\begin{array}{l}\text { facility located in } \\
\text { frequented environment }\end{array}$ & 0,75 & 0,75 & 0,75 & 1 & 0,75 & 0,75 & 0,75 & 0 \\
\hline
\end{tabular}

Tab. 7. Resistances of facilities based on user preferences

\begin{tabular}{ccc}
\hline & commuting employee & $\begin{array}{c}\text { employee with high mobility } \\
\text { demands }\end{array}$ \\
\hline suburban parking area & 2,7 & 3,95 \\
\hline guarded park and ride facility & $\mathbf{1 , 7 5}$ & 2,15 \\
\hline $\begin{array}{l}\text { automated multi-storey car park, in } \\
\text { the downtown }\end{array}$ & 1,825 & $\mathbf{1 , 2 5}$ \\
\hline Source: (own edition) & & \\
\hline
\end{tabular}


Table 5. illustrates the above mentioned relations, through three examples. The table contains static and dynamic vector. The latter depends on e.g. actual traffic. In the example rushhour traffic has been supposed, when the city centre is close to saturation. Aim of the traffic control strategy is reduction of entering vehicles into the city centre.

Values of personal preference vectors: users give answers for questions regarding to static and dynamic features. Answers are very different, thus they are ranked and they are converted to a continuous 0-1 scale, taking general user habits into account the latter can be measured by surveys and questionnaires. ( 0 is the least important and 1 is the most important.) Exact values are depending on general user habits, average occupancy, etc. These elements (numbers from the $0-1$ interval) are the coordinates of the personal preference vectors. Calculating scalar product of vectors by Eq. (1)), the facilities are ranked with consideration to personal preferences.

$\bar{p}_{s}$ determination of personal preference vector of static features: $\bar{p}_{s}=\left[\begin{array}{llllll}p_{s 1} & p_{s 2} & p_{s 3} & p_{s 4} & p_{s 4} & p_{s 6}\end{array}\right]$

Please specify how important are the following aspects for you:

- $\mathbf{p}_{\mathbf{s} 1}$ - location? (close to frequented facilities, advantageous public transport connections, short walking distances, etc.)

- $\mathbf{p}_{\mathbf{s} 2}$ - layout? (easy parking movements, simple manoeuvrability, visible curves, etc.)

- $\mathbf{p}_{\mathbf{s} 3}$ - terms of use? ([conditions regard to vehicles and/or users], payment methods [card, cash], etc.)

- $\mathbf{p}_{\mathbf{s} 4}$ - simplicity of information handling? (operations during entering and exiting, payment operations, information about public transport, etc.)

- $\mathbf{p}_{\mathbf{s 5}}$ - safety systems? (active and passive systems enhancing traffic safety)

- $\mathbf{p}_{\mathbf{s 6}}$ - security systems? (24/7 safeguarding, permanent dispatcher surveillance, user and vehicle identification, etc.)

$\bar{p}_{d}$ determination of personal preference vector of dynamic features: $\bar{p}_{d}=\left[\begin{array}{ll}p_{d 1} & p_{d 2}\end{array}\right]$

Please specify:

- $\mathbf{p}_{\mathbf{d} 1}$ - how far do you accept the recommended parking place offered by the information system?

- $\mathbf{p}_{\mathbf{d} 2}$ - how important are parking fees for you?

Table 6 illustrates the personal preferences for different user groups (in this example values are discrete, the 0-1 interval is divided for 5 parts.).

Calculating the scalar product of the vectors based on equation Eq. (1)), users get a resistance value for each facility. Table 7. contains the results of the example. Bold numbers indicate the better choice in the actual traffic situation. Modification of traffic conditions and/or management strategy implies change of resistance values.

Resistances of the certain facilities are very close to each other in some cases or they are equal. In latter case user make the selection.

In this case the theoretical maximum value of resistance factor is 8 . This value can modify when the operators take more or less features into consideration. The theoretical maximum is equal with the number of the coordinates of static and dynamic vectors.

The complete resistant calculation procedure can be decomposed for three parts: (1) data recording; (2) data procession and evaluation; (3) information provision. In this paper authors have dealt only with data procession and evaluation in detail. Analysis of the other two parts can be made in future researches.

\section{Future works, new information technology and its potentials}

The growing penetration of mobile communication and mobile internet, as well as decreasing communication costs will result new smartphone based transportation and traffic information applications in the following years. It is expected that the legal environment will change too. Thus data from mobile network can be used also for new non-communication purposes (e.g. traffic prediction) or they can be sold. Traffic and transport information applications will collect more and more data; therefore management of mobility demands can be more efficient.

Possible data sources: users with their mobile devices, with location information. There are two methods for collection of location information.

- Data from the cellular network: position of mobile phones can be traced by GSM cell information. [Spatial accuracy depends on location and spatial coverage of base stations.] The accuracy is not as precise as geographic coordinates, but movement of human masses can be mapped and prognosis can be calculated considering the trends.

- Data from smartphone: Smartphone with GPS receiver can transmit its actual position to a predefined recipient (e.g. traffic management centre, dispatcher centre, etc). Using GPS coordinates much more accurate prognosis can be estimated. Smartphone can transmit some other data to transport service companies too through the mobile internet $(3 \mathrm{G}, 4 \mathrm{G})$ network (origin, destination, personal preferences, etc.).

It is predictable, that in the near future (in the next few decades) vehicle-driving will change significantly due to the development of intelligent vehicles functions. Automated vehicle will take over most of the driver-related activities and users have to input only the destination and personal preferences. 


\section{Conclusions}

Parking management has great importance in the coordinated mobility and traffic management. The quarter or one third of the total traffic relates to parking place searching in congested urban areas, during the peak periods. The appropriate and adequate information about the number of free places, their location, etc. can reduce even by $30 \%$ the traffic volume in some cases. In this article the different parking solutions and the conception of an intelligent network-wide parking management system have been presented. A method has been elaborated, which coordinates the parking demands and capacities in real time, takes actual traffic situation, personal preferences and traffic control strategy also into consideration. It can be used in navigation and route planning systems. The calculation method has been illustrated by an example. It is beneficial for both users and operators. The parking management has to be integrated in the traffic management and parking related measures have to be adjusted to traffic management measures. This action and the operation of the parking management should be the duty of the local municipalities. Privately and state owned parking facilities should be interconnected in order to ensure the seamless and correct use of the complete traffic management. State-of-the-art solutions are operating in this way.

\section{Acknowledgement}

TÁMOP-4.2.2.C-11/1/KONV-2012-0012: "Smarter Transport" - IT for co-operative transport system - The Project is supported by the Hungarian Government and co-financed by the European Social Fund.

\section{References}

1 Sándor Z, Nagy E, Overtaking ban for heavy goods vehicle in Hungary on the national motorway network, Pollack Periodica, 7(1), (2012), 83-95, DOI 10.1556/Pollack.7.2012.1.8

2 Rye T, Ison S, Overcoming barriers to the implementation of car parking charges at UK workplaces, Transport Policy, 12(1), (2005), 57-64, DOI 10.1016/j.tranpol.2004.11.002

3 Marsden G, The evidence base for parking policies - a review, Transport Policy, 13(6), (2006), 447-457, DOI 10.1016/j.tranpol.2006.05.009

4 D'Acierno L, Gallo M, Montella B, Optimisation models for the urban parking pricing problem, Transport Policy, 13(1), (2006), 34-48, DOI 10.1016/j.tranpol.2005.08.001

5 Tacconi D, Miorandi D, Carreras I, Chiti F, Fantacci R, Using wireless sensor networks to support intelligent transportation systems, Ad Hoc Networks, 8(5), (2010), 462-473, DOI 10.1016/j.adhoc.2009.12.007

6 Yan G, Yang W, Rawat D, Olariu S, SmartParking: A Secure and Intelligent Parking System, IEEE Intelligent Transportation Systems Magazine, 3(1), (2011), 18-30, DOI 10.1109/MITS.2011.940473

7 Oláh F, Parking management systems, Scientific Review of Transport, 53(9), (2003), 350-359.

8 Teodorović D, Lučić $\mathbf{P}$, Intelligent parking systems, European Journal of Operational Research, 175(3), (2006), 1666-1681, DOI 10.1016/j.ejor.2005.02.033

9 Mitchell D, Ghent P, ExpressPark ${ }^{\mathrm{TM}}$ - An Intelligent Parking Management System for Downtown Los Angeles, In: ITE Western District Annual Meeting; Anchorage.
10 Rodier CJ, Shaheen SA, Transit-based smart parking: An evaluation of the San Francisco Bay area field test, Transportation Research Part C: Emerging Technologies, 18(2), (2010), 225-233, DOI 10.1016/j.trc.2009.07.002

11 Marinho M, Vianna B, da Silva Portugal L, Balassiano R, Intelligent transportation systems and parking management: implementation potential in a Brazilian city, Cities, 21(2), (2004), 137-148, DOI 10.1016/j.cities.2004.01.001

12 Litman T, Parking Management, Comprehensive Implementation Guide, Victoria Transport Policy Institute, 2010, http://www.vtpi.org/park_ man_comp.pdf

13 Trullols O, Fiore M, Casetti C, Chiasserini C, Barcelo Ordinas J, Planning roadside infrastructure for information dissemination in intelligent transportation systems, Computer Communications, 33(4), (2010), 432-442, DOI 10.1016/j.comcom.2009.11.021

14 Te Brömmelstroet M, Bertolini L, Integrating land use and transport knowledge in strategy-making, Transportation, 37(1), (2010), 85-104, DOI 10.1007/s11116-009-9221-0

15 Farag S, Lyons G, Explaining public transport information use when a car is available: Attitude theory empirically investigated, Transportation, 37(6), (2010), 897-913, DOI 10.1007/s11116-010-9265-1

16 Soltész T, Kózel M, Csiszár C, Centgráf T, Benyó B, Information system for road infrastructure booking, Periodica Polytechnica Transportation Engineering, 39(2), (2011), 55-62, DOI 10.3311/pp.tr.2011-2.02

17 Rye T, Cowan T, Ison S, Expansion of a Controlled Parking Zone (CPZ) and its Influence on Modal Split: The Case of Edinburgh, Transportation Planning and Technology, 29(1), (2006), 75-89, DOI 10.1080/03081060600585368

18 Ottomanelli M, Dell'Orco M, Sassanelli D, Modelling parking choice behaviour using Possibility Theory, Transportation Planning and Technology, 34(7), (2011), 647-667, DOI 10.1080/03081060.2011.602846 